\begin{tabular}{|c|c|}
\hline \multirow{3}{*}{ 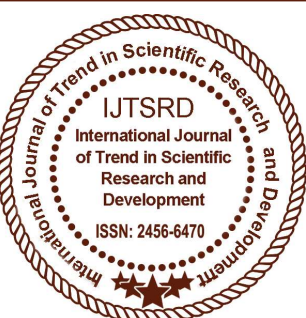 } & $\begin{array}{l}\text { International Journal of Trend in Scientific } \\
\text { Research and Development (IJTSRD) }\end{array}$ \\
\hline & Access Journal \\
\hline & ISSN No: 2456 - 6470 | www.ijtsrd.com | Volume - 2 | Issue -3 \\
\hline
\end{tabular}

\title{
Utilization of Waste Glass as Cement Replacement in PPC Concrete
}

\author{
Sudhir Kumar \\ Department of Civil Engineering, UIET, \\ Babasaheb Bhimrao Ambedkar University, \\ Lucknow, Uttar Pradesh, India
}

\author{
Manish Chaudhary \\ Department of Civil Engineering, Sam Higginbottom \\ Institute of Agriculture Technology and Science, \\ Allahabad, Uttar Pradesh, India
}

\section{ABSTRACT}

In the Present era, the globalizations due to the rapid growing of construction are insufferable burden on environment and rapid weakening of respective natural resources. All construction activities require more or less natural material like aggregates which cause rapid weakening of the same due to high consumption. On the other hand production of one ton cement is responsible for emission of 0.9 ton $\mathrm{CO} 2$. Glass is a widely used product throughout the world and it is used in many forms in day-to-day life; it is versatile, durable and reliable. Glass has limited life duration and after use it is either stock piled or sent to landfills. Since glass is non-biodegradable, the large amount of glass is disposed of in landfill it's not provide an environment friendly solution. Hence, there is strong need to utilize waste glasses. In present experimental investigation -waste glass powders have been used as a partial replacement to the concrete ingredient i.e. cement and the mechanical properties like compressive strength and split tensile strength are measured. For checking strength effect of replacement of cement by glass powder, the cement is replaced at $05 \%, 10 \%, 15 \%, 20 \%$ and $25 \%$.

Keywords: Waste glass, Compressive strength, Split tensile strength, PPC, Concrete

\section{INTRODUCTION}

Concrete is a primary building construction material in the world, consumed man made material About at 11 billion tons or approximately 1.7 tons per every living human being was consumed concrete in the world. Production of cement is an energy intensive and highly polluting process which contributes about
5 to $8 \%$ to global $\mathrm{CO}_{2}$ emission and account s for $3 \%$ of total ( $5 \%$ of industrial) energy consumption in world wide. Production of each ton of cement emits one ton of carbon dioxide $\left(\mathrm{CO}_{2}\right)$ to atmosphere. Manufacturing of cement is also an energy intensive process, which ranks third after aluminum and steel production in terms of energy consumption. Close to 5.5 million BTU (British thermal unit) of energy is consumed for production of a ton of cement. The energy used for production of cement accounts for more than $90 \%$ of the total energy required for production of cement. In spite of major efforts in recent decades, significant gain in the fuel-efficiency of cement production plants has been realized. The use of solid waste materials or industrial by products as partial replacement for cement in concrete is a viable strategy for reducing the use of Portland cement, and thus reducing the environmental and energy impacts of concrete production. Glass is a widely used product throughout the world; it is versatile, durable and reliable. The uses of glass ranges considerably, therefore waste glass is unnecessary, stockpiled or land filled. About million tons of waste glass is generated and around large percent of this glass is disposed of in landfills. This pattern has influenced environmental organizations to pressure the professional community to lower the amount of glass being unnecessary as well as find use to the non-recycled glass in new applications. In relation, the recycling of waste glass as a constituent in concrete gives waste glass a sustainable unconventional to land filling and therefore makes it economically possible. The proposed investigation of utilizing waste glass powder(GLP) in concrete as 
partial replacement of cement as well as the use oq) crushed glass particles(CGP) retained on $1.18 \mathrm{~mm}$, which offers important benefits related to strength of concrete as well as it is eco-friendly. Vijayakumar $\boldsymbol{e t}$ al. (2013) found that replacement of waste glass powder in cement by $20 \%, 30 \%$ and $40 \%$ increases the compressive strength by $19.6 \%, 25.3 \%$ and $33.7 \%$ ) respectively. Sameer et al. (2015) found that concrete) with using waste glass powder and crushed glass particles has a very high workability from control sample. This result achieved from the slump test that use of waste glass powder were will increase the workability of concrete. In term of strength, concrete with using waste glass powder averagely have higher strength at 28 days. Conventional concrete shows at 7 days compressive strength as $14.51 \mathrm{~N} / \mathrm{mm}^{2}$, split tensile strength of $1.55 \mathrm{~N} / \mathrm{mm} 2$ and flexural strength of $1.97 \mathrm{~N} / \mathrm{mm}^{2}$. Conventional concrete shows at 28 days compressive strength as $19.25 \mathrm{~N} / \mathrm{mm}^{2}$, split tensile strength of $1.88 \mathrm{~N} / \mathrm{mm}^{2}$ and flexural strength of $2.72 \mathrm{~N} / \mathrm{mm}^{2}$. Shruthi.S et al. (2015) found that concrete with utilizing waste glass powder has a high workability from control test. The outcome accomplished from the slump test clarifies that by utilizing waste glass powder will expand the workability of concrete. In term strength, concrete with using waste glass powder averagely have higher strength at 14 days yet once the concrete reached at 28 days the control mix give more higher worth contrast with mix that contained waste glass powder yet at the same time give high value for M30.

\section{Material and Methods}

1) Cement- In this study, Portland Pozzolana Cemen5) (fly ash based) of single batch was used conforming to IS 1489(part I):1991 specification. Properties of PPC are as listed below in table 1.

Table-1, Properties of Portland Pozzolana cement (PPC)

\begin{tabular}{|l|l|}
\hline \multicolumn{1}{|c|}{ Properties } & \multicolumn{1}{c|}{$\begin{array}{c}\text { Result } \\
\text { value }\end{array}$} \\
\hline Initial setting time & 145 minutes \\
\hline Final setting time & 315 minutes \\
\hline Standard consistency \% & $31.6 \%$ \\
\hline $\begin{array}{l}\text { Fineness(\% retained on } 90 \mu \text { in } \\
\text { sieve) }\end{array}$ & $3.7 \%$ \\
\hline Specific gravity & 2.73 \\
\hline $\begin{array}{l}\text { Soundness(Le-chatelier } \\
\text { expansion) }\end{array}$ & $0.5 \mathrm{~mm}$ \\
\hline 7 Days compressive strength & $33 \mathrm{MPa}$ \\
\hline 28 Days compressive strength & $44 \mathrm{MPa}$ \\
\hline
\end{tabular}
6)
2). Fine Aggregate- Fine aggregate (FA) used in this investigation was locally available the natural river sand passing completely through $4.75 \mathrm{~mm}$ aperture size sieve and conforming to zone II as per IS:3831970 specification. Its fineness modulus and specific gravity were 2.74 and 2.35 respectively.

3). Coarse Aggregate- A Combined grading of the two individual $20 \mathrm{~mm}$ and $10 \mathrm{~mm}$ Nominal size coarse aggregate $(20 \mathrm{~mm} \mathrm{CA} \mathrm{\&} 10 \mathrm{~mm} \mathrm{CA})$ gradings was used with the ratio of these coarse aggregates as 60:40 respectively. Particle size distribution curve of the Achieved Combined coarse aggregate with these two $(20 \mathrm{~mm}$ and $10 \mathrm{~mm})$ coarse aggregate by the Recorded sieve analysis test result with permissible limits (UPL \& LPL), Properties of the Achieved Combined coarse Aggregate (CCA) of $20 \mathrm{~mm}$ Nominal size are shown in Table 2.

\begin{tabular}{|c|c|c|}
\hline \multicolumn{2}{|l|}{ Properties } & \multirow{2}{*}{$\begin{array}{l}\text { Result } \\
\text { value } \\
5.854\end{array}$} \\
\hline $\begin{array}{l}\text { Fineness } \\
\text { Modulus }\end{array}$ & $\begin{array}{l}10 \mathrm{~mm} \\
\text { Aggregate }(10 \mathrm{~mm} \\
\mathrm{CA})\end{array}$ & \\
\hline ar & $\begin{array}{l}20 \\
\text { Aggregate }(20 \mathrm{~mm} \\
\mathrm{CA})\end{array}$ & 7. 104 \\
\hline nent: & $\begin{array}{l}\text { Combined Coarse } \\
\text { Aggregate(CCA) }\end{array}$ & 6.479 \\
\hline \multicolumn{2}{|c|}{ Water absorption (\%) } & 0.84 \\
\hline \multicolumn{2}{|c|}{ Specific gravity } & 2.60 \\
\hline
\end{tabular}

4). Waste Glass- Waste glass locally available at Batra shops, has been collected and made into glass powder. Glass waste is very hard material. Before adding glass powder in the concrete it has to be powdered to desired size. In this studies glass powder was made manually by using impact container and then passing through 90 micron IS sieve in table the physical and chemical properties are presented.

\begin{tabular}{|l|l|l|}
\hline \multicolumn{2}{|c|}{ Properties } & \multicolumn{2}{|c|}{$\begin{array}{l}\text { Result } \\
\text { Value }\end{array}$} \\
\hline \multirow{2}{*}{$\begin{array}{l}\text { Physical } \\
\text { Properties }\end{array}$} & Specific Gravity & 2.65 \\
\cline { 2 - 3 } & Fineness Passing $90 \mu$ & $97 \%$ \\
\cline { 2 - 3 } & Fineness Passing $150 \mu$ & $100 \%$ \\
\hline $\begin{array}{l}\text { Chemical } \\
\text { Properties }\end{array}$ & pH & 10.25 \\
\cline { 2 - 3 } & Colour & White \\
\hline
\end{tabular}


5) Super Plasticizer - Sulphonated naphthalene formaldehyde (SNF) based Super plasticizer (KEM SUPLAST $101 \mathrm{~S}$ ) of Chembond chemicals was used which conforms to IS:9103-1999 specifications. It was in liquid form compatible with the used Cement, brown in colour having specific gravity 1.2 and it showed good deflocculation and dispersion with cement particles to enhance the workability of concrete mix.

6) Mix Design of the Referral Concrete - M-25 grade of concrete conforming to IS:10262-2009 guidelines was designed as the referral concrete with the mix proportion of (1:1.56:3) and water-cement ratio(W/C) of 0.44 by weight taking with $0.6 \%$ super plasticizer dose by weight of cement.

7) Water - Potable water was used for mixing the concrete mix in entire investigation and for curing the concrete in the determination of the optimal percentage of stone dust as fine aggregate replacement.

\section{Experimental design}

The cube sand cylinders were cast in steel moulds of inner dimensions of cube, $150 \times 150 \times 150 \mathrm{~mm}$, and cylinder $150 \mathrm{~mm}$ diameter $\times 300 \mathrm{~mm}$ long. All the materials are weighted as per mix proportion of 1:1.56:3 with a W/C ratio of 0.44 which correspond to M25 grade of concrete. Cement is replaced by Waste glass powder. Each mix comprises of various percentages of cement replacement material in increasing order i.e. $5 \% 10 \%, 15 \%, 20 \%$, and $25 \% \mathbf{B}$ ) respectively in replacement. The specimens were cured for a period of 7 days, 14 days and 28 days.

\section{Result and Discussion}

A) Workability -Workability is property of concrete which determine ease in mixing, placing and compaction of concrete. The results of workability in terms of slump for concrete made using waste glass as cement replacement are shown in table 4 . The same results are given in figure -1 , for visual observation and having the idea about variation pattern. It was observed that at constant dose of Super plasticizer $(0.6 \%)$ workability of concrete made using waste glass as cement replacement was increased with replacement level. This increase was due to the increasing content of waste glass with is hydrophobic in nature. Resulting is more availability of water as compare to conventional concrete.
Table 4 - Variation of Slump at different replacement levels $(\%)$ of cement

\begin{tabular}{|l|l|l|}
\hline S.No. & $\begin{array}{l}\text { Replacement level } \\
(\%) \text { Waste glass }\end{array}$ & $\begin{array}{l}\text { Slump }(\mathrm{mm}) \text { with } \\
\mathbf{0 . 6} \% \text { with Super } \\
\text { plasticizer }\end{array}$ \\
\hline $\mathbf{1}$ & 0 & 65 \\
\hline $\mathbf{2}$ & 5 & 55 \\
\hline $\mathbf{3}$ & 10 & 73 \\
\hline $\mathbf{4}$ & 15 & 84 \\
\hline $\mathbf{5}$ & 20 & 80 \\
\hline $\mathbf{6}$ & 25 & 90 \\
\hline
\end{tabular}

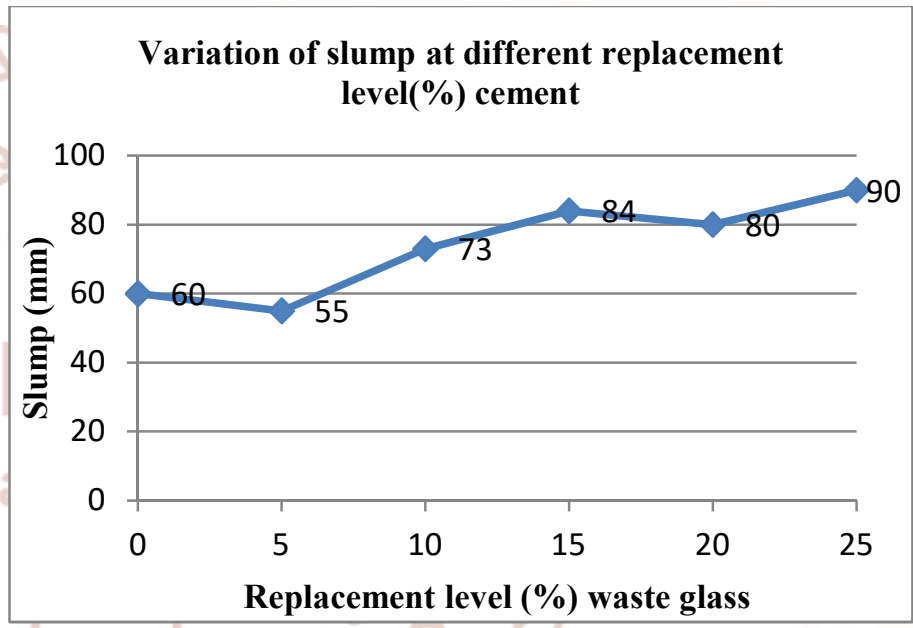

\section{Figure-1 Variation of slump at different replacement level (\%) cement}

Compressive Strength - Compressive strength of the concrete cube specimen was calculated by dividing the maximum load applied to the specimen during the test by the cross sectional area. The average of three values of compressive strength was taken as the representative compressive strength. In test, cube specimen was placed in the CTM machine in such manner that the load was applied to the opposite sides of the concrete cube as cast, that is, not to the top and bottom as per IS: 516-2004 specification. Result of compressive strength of specimens cast for different replacement levels of fine aggregate with stone dust in Portland Pozzolana Cement (PPC) concrete, and a constant dose of super plasticizer are discussed here in after. The average compressive strength of concrete for 7 days, 14 days and 28 days were tested as per IS $516-2004$ guidelines and results are tabulated in table-5 and its graphical representation on figure- 2 (line chart). It was observed that the compressive strength of specimen at $15 \%$ replacement level of cement with waste glass powder was more than designed value of conventional concrete which shows 
International Journal of Trend in Scientific Research and Development (IJTSRD) ISSN: 2456-6470

suitability of waste glass in concrete as partial replacement of cement from compressive strength point of view. The 7 days compressive strength variations within $21.34 \%$ maximum strength and attains on 20 percent replacement of cement with waste glass. The 28 days compressive strength gradually increased with the increase of all replacement level of waste glass. At 15 percent replacement of waste glass concrete attains maximum value and then compressive strength decreases with increases replacement level of waste glass. The results of compressive strength of concrete made using waste glass as cement replacement are shown in table 5 . The same results are given in figure 2 for visual observation and having the idea about variation pattern. It is evident from table 5 compressive strength of concrete made using waste glass as cement replacement was more than conventional concrete at all the replacement level of 28 days, however strength is maximum at $15 \%$ replacement level.

\section{Table -5 Compressive strength Result}

\begin{tabular}{|c|c|c|c|c|c|}
\hline \multirow[t]{2}{*}{ S.No } & \multirow{2}{*}{$\begin{array}{l}\text { Cube } \\
\text { Designati } \\
\text { on }\end{array}$} & \multirow{2}{*}{$\begin{array}{l}\text { Replac } \\
\text { ement } \\
\text { Level } \\
\text { of } \\
\text { Waste } \\
\text { Glass } \\
(\%)\end{array}$} & \multicolumn{3}{|c|}{$\begin{array}{l}\text { Compressive } \\
\text { Strength(N/mm² }\end{array}$} \\
\hline & & & $\begin{array}{l}7 \\
\text { Days } \\
\end{array}$ & $\begin{array}{l}14 \\
\text { Days }\end{array}$ & $\begin{array}{l}\mathbf{2 8} \\
\text { Days } \\
\text { ese }\end{array}$ \\
\hline 1 & A0 & 0 & $\begin{array}{l}18.5 \\
6\end{array}$ & $\begin{array}{l}22.4 \\
5\end{array}$ & 31.74 \\
\hline 2 & A1 & 5 & $\begin{array}{l}19.1 \\
5\end{array}$ & $\begin{array}{l}24.1 \\
5\end{array}$ & 32.67 \\
\hline 3 & A2 & 10 & $\begin{array}{l}20.4 \\
6\end{array}$ & $\begin{array}{l}25.5 \\
6\end{array}$ & 34.45 \\
\hline 4 & A3 & 15 & $\begin{array}{l}21.3 \\
5\end{array}$ & $\begin{array}{l}26.0 \\
4\end{array}$ & 35.44 \\
\hline 5 & A4 & 20 & $\begin{array}{l}22.5 \\
2\end{array}$ & $\begin{array}{l}24.7 \\
4\end{array}$ & 34.56 \\
\hline 6 & A5 & 25 & $\begin{array}{l}20.1 \\
8\end{array}$ & $\begin{array}{l}23.8 \\
6\end{array}$ & 33.67 \\
\hline
\end{tabular}

Compressive strength of waste glass concrete

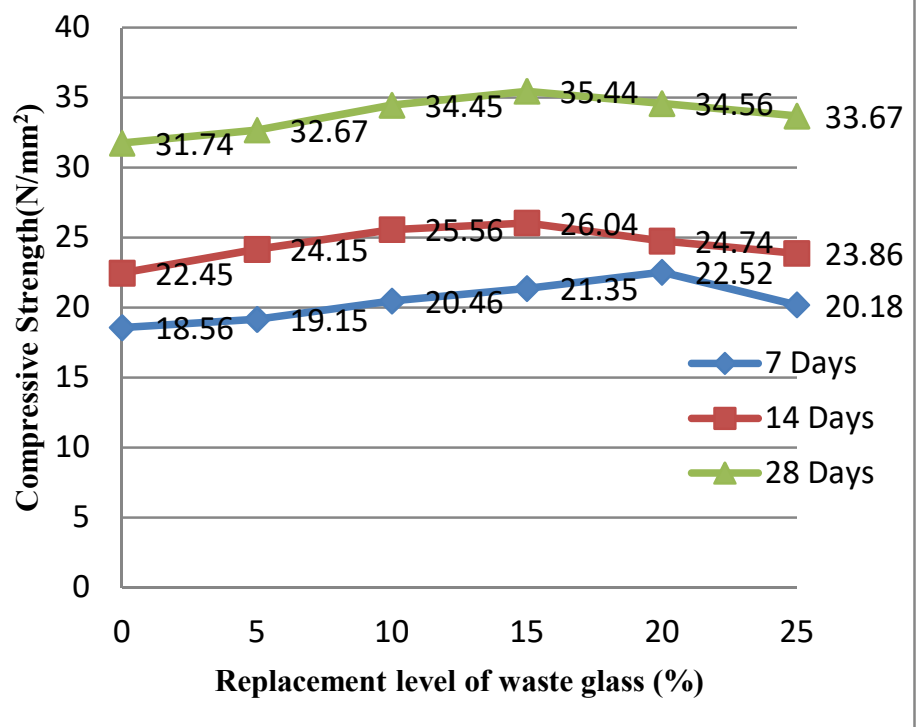

Figure-2 Variation of compressive strength with replacement level $(\%)$ of cement

C) Split tensile strength-The split tensile strength of concrete mixes by partial replacement of cement by waste glass powder was cast cylinder and tested at 7, 14 and 28 days. Thus the result split tensile strength of concrete increases with increased replacement level of waste glass powder which can be supplanted up to $20 \%$ as indicated in visual representation in table- 6 and Figure-3.

D)

Table-6 Split Tensile Strength Result

\begin{tabular}{|c|c|c|c|c|c|}
\hline \multirow[t]{2}{*}{ S.No } & \multirow{2}{*}{$\begin{array}{l}\text { Cube } \\
\text { Desig } \\
\text { natio } \\
\text { n }\end{array}$} & \multirow{2}{*}{$\begin{array}{l}\text { Replac } \\
\text { ement } \\
\text { Level } \\
\text { of } \\
\text { Waste } \\
\text { Glass } \\
(\%)\end{array}$} & \multicolumn{3}{|c|}{$\begin{array}{l}\text { Split Tensile } \\
\text { Strength }\left(\mathrm{N} / \mathrm{mm}^{2}\right)\end{array}$} \\
\hline & & & $\begin{array}{l}7 \\
\text { Days }\end{array}$ & $\begin{array}{l}14 \\
\text { Days }\end{array}$ & \begin{tabular}{|l|}
28 \\
Days
\end{tabular} \\
\hline 1 & B0 & 0 & 1.78 & 1.96 & 2.28 \\
\hline 2 & B1 & 5 & 2.15 & 2.33 & 2.78 \\
\hline 3 & B2 & 10 & 2.45 & 2.58 & 2.95 \\
\hline 4 & B3 & 15 & 2.68 & 2.82 & 3.18 \\
\hline 5 & B4 & 20 & 2.23 & 2.40 & 2.55 \\
\hline 6 & B5 & 25 & 1.88 & 2.18 & 2.30 \\
\hline
\end{tabular}




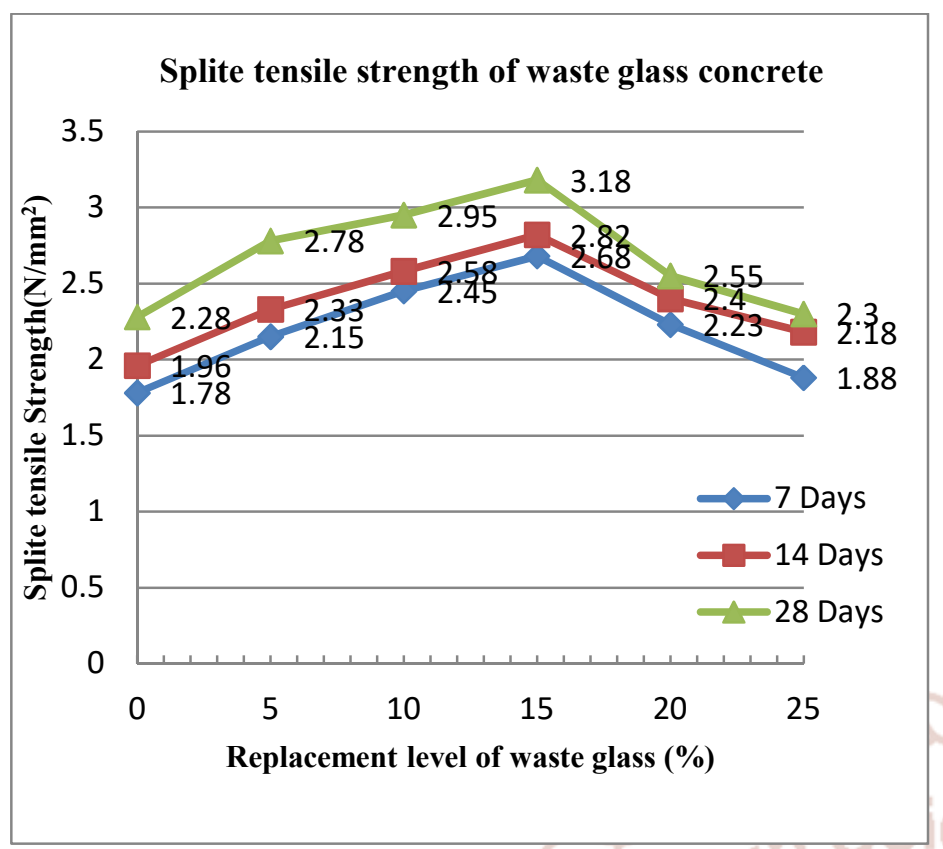

\section{Figure-3 Variation of Split Tensile Strength with replacement level (\%) of cement}

\section{Conclusion}

On the basis of above investigation it can be concluded that-

1. Waste glass is to be used as cement replacement of Portland Pozzolana cement (PPC) in concrete as partially.

2. While using waste glass as partial replacement of Portland Pozzolana Cement (PPC) in concrete increased the workability with increased in replacement level.

3. Compressive strength of concrete made using waste glass used as partial replacement of cement. The optimum replacement level of waste glass in cement is $15 \%$.

4. Split tensile strength of concrete made using waste glass as partial replacement of cement.

5. Use of waste glass powder as cement in concrete is beneficial in different manners such as environmental aspects and strength criteria also.

\section{References}

1) Shruthi.S, Chandrakala S, G Narayana(2015) "Partial replacement of cement in concrete using waste glass powder and $\mathrm{m}$-sand as fine aggregate" IJRET: International Journal of Research in Engineering and Technology eISSN: 2319-1163 pISSN: 2321-7308

2) Sameer Shaikh ,S.S.Bachhav ,D.Y. Kshirsagar(2015) "Effective Utilisation of
Waste Glass in Concrete." Int. Journal of Engineering Research and Applications www.ijera.com ISSN: 2248-9622, Vol. 5, Issue 12, (Part - 4) December 2015, pp.01-04

3) Shivacharan Singh, Vikas Srivastava, V.C. Agarwal (2015) "Glass Waste in Concrete: Effect on Workability and Compressive Strength" International Journal of Innovative Research in Science, Engineering and Technology Vol. 4, Issue 9, September 2015.

4) M. Adaway \& Y. Wang(2015) "Recycled glass as a partial replacement for fine aggregate in structural concrete - Effects on compressive strength" Electronic Journal of Structural Engineering 14(1) 2015.

5) S.P. Gautam, Vikas Srivastava and V.C. Agarwal (2012) "Use of glass wastes as fine aggregate in Concrete" (C) Youth Education and Research Trust (YERT)2012.

6) IS $383-1997$ Specification for coarse and fine aggregate from natural sources for concrete, Bureau of Indian standards, New Delhi.

7) IS 10262 - 2009 Concrete mix proportioning guidelines, Bureau of Indian standards, New Delhi.

8) IS 14858 - 2000): Requirements for compression testing machine used for testing of concrete and mortar, Bureau of Indian standards, New Delhi.

9) IS 516 - 2004 Method of test for strength of concrete, Bureau of Indian standards, New Delhi.

10) IS 5816 - 1999 Method of test for Splitting tensile strength of concrete, Bureau of Indian standards, New Delhi.

11) Agamuthu P, Fauziah SH, Kahlil K. Evolution of solid waste management in Malaysia: impacts and implications of the solid waste bill. J Mater Cycles Waste Manage (Oxford) 2009;11:96 103.

12) Agarwal, S. K. (2006). "Pozzolanic activity of various siliceous materials." Cement and Concrete Research, 36(9), 1735-1739.

13) Dr. G.Vijayakumar, Ms H. Vishaliny, Dr. D. Govindarajulu (2013)"Studies on Glass Powder as Partial Replacement of Cement in Concrete Production" International Journal of 
International Journal of Trend in Scientific Research and Development (IJTSRD) ISSN: 2456-6470

Emerging Technology and Advanced Engineering Website: www.ijetae.com (ISSN 2250-2459, ISO 9001:2008 Certified Journal, Volume 3, Issue 2, February 2013)

14) Andreola, F., Barbieri, L., Corradi, A., Lancellotti, I., Falcone, R. and Hreglich, S. (2005) Glass-Ceramics Obtained by the Recycling of End of Life Cathode Ray Tubes Glasses. Waste Management, 25, 183189.http://dx.doi.org/10.1016/j.wasman.2004. 12.007

15) Jurga Šeputytė-Jucikė \& Marijonas Sinica (2016) "The effect of expanded glass and polystyrene waste on the properties of lightweight aggregate concrete", Engineering Structures and Technology http://www.tandfonline.com Volume 8, 2016 Issue 1

16) Nasser Almesfer and Jason Ingham (2014) "Effect of Waste Glass on the Properties of Concrete", Journal of Materials In Civil Engineering, Volume 26 Issue 11 -November 2014

17) Eberstein, M., Reinsch, S., Müller, R., Deubener, J. and Schiller, W.A. (2009) "Sintering of Glass Matrix Composites with Small Rigid Inclusions". Journal of the European Ceramic Society, 29, 24692479. http://dx.doi.org/10.1016/j.jeurceramsoc .2009 .02 .007
18) Fluegel, A. (2007) Glass Viscosity Calculation Based on a Global Statistical Modelling Approach. European Journal of Glass Science and Technology Part A: Glass Technology, 48, 13-30.

19) Boccaccini, A.R. (1994) Sintering of Glass Matrix Composites Containing A12O3 Platelet Inclusions. Journal of Materials Science, 29, 4273-

4278. http://dx.doi.org/10.1007/BF00414210

20) Joseph Wartman, M.ASCE; Dennis G. Grubb, M.ASCE; and A. S. M. Nasim(2004) "Select Engineering Characteristics of Crushed Glass", Engineering Structures and Technology http://www.tandfonline.com Volume 16, Issue 6 December 2004

21) Arnon Bentur (1989) "Silica Fume Treatments as Means for Improving Durability of Glass Fiber Reinforced Cements", Volume 1, Issue 3- August 1989.

22) Ablam Zido, Monique Tohoue Tognonvi, Arezki Tagnit-Hamou(2017) "Effect of Glass Powder on Concrete Sustainability" New Journal of Glass and Ceramics, 2017, 7, 34-47 http://www.scirp.org/journal/njgc

ISSN Online: 2161-7562, ISSN Print: 2161-7554. 